\title{
Seo vaccines market worth 48.03 billion USD by 2021
}

Volume 2 Issue 5 - 2016

\section{Opinion}

The report " Vaccines Market by Technology (Live Attenuated, Toxoid, Conjugate, Inactivated \& Subunit, Recombinant), Disease Indication (Pneumococcal, Influenza, HPV, Hepatitis, Rotavirus, DTP, Polio, MMR), End User (Pediatrics, Adults) \& Type - Forecasts to 2021 ", report provides a detailed overview of the major drivers, restraints, challenges, opportunities, current market trends, and strategies impacting the vaccines market along with the estimates and forecasts of the revenue and market share analysis. ${ }^{1}$

The global vaccines market is expected to reach USD 48.03 Billion by 2021 from USD 32.24 Billion in 2016 at a CAGR of $8.3 \%$ from 2016 to 2021 . The major factor driving the growth of this market are high prevalence of diseases, rising government and nongovernment funding for vaccine development, increasing investments by companies, and increasing focus on immunization programs.

The report segments this market based on technology, type, disease indication, end-users, and regions. Among the various technologies, the conjugate vaccines segment is expected to account for the largest share of the market. This segment is projected to grow at the highest CAGR from 2016 to 2021. The high growth of this segment can be attributed to the increasing government support for vaccine development and rising company investments.

On the basis of type, the vaccines market is segmented into monovalent vaccines and multivalent vaccines. The monovalent vaccines segment is expected to account for the largest share of the global vaccines market in 2016 due to rising prevalence of diseases and increasing government and non-government initiatives for vaccine $R \& D$ activities.

Disease indication, included in the vaccines market are pneumococcal disease, influenza, diphtheria, tetanus, and pertussis (DTP), hepatitis, rotavirus, varicella, meningococcal disease, polio, measles, mumps, and rubella (MMR), human papilloma virus (HPV) infection, and others. The pneumococcal disease segment is expected to account for the largest share of the global vaccines market in 2016. High incidence of pneumococcal infections is driving the growth of this market.

End-users, included in the vaccines market are pediatrics and adults. The pediatrics segment is expected to account for the largest share of the global vaccines market in 2016. Increasing prevalence of diseases in children and rising number of awareness programs to promote vaccination will drive the growth of this market.

\author{
Parikshit Thakur \\ Mumbai/Sant Gadge Baba Amravati University, India
}

Correspondence: Parikshit Thakur, Mumbai/Sant Gadge Baba Amravati University, P. R. Pote (Patil) Education \& Welfare Trust's Group of Institutions's College of Engineering \& Management, Amravati, India, Email parkshitthakur1998@gmail.com

Received: September 08, 2016 | Published: September 14, 2016

Based on regions, the global vaccines market is segmented into North America, Europe, Asia, and the Rest of the World (RoW). North America is expected to account for the largest share of the market during the forecast period. Growth in this segment is driven by increasing government funding for vaccine research and immunization.

Key players in the vaccines market include Astellas Pharma Inc. (Japan), CSL Limited (Australia), Emergent BioSolutions, Inc. (U.S.), GlaxoSmithKline, plc. (U.K.), Johnson \& Johnson (U.S.), MedImmune, LLC (U.S.), Merck \& Co. (U.S.), Pfizer, Inc. (U.S.), Sanofi Pasteur (France), and Serum Institute of India Pvt. Ltd. (India). ${ }^{2}$

\section{Acknowledgments}

None.

\section{Conflicts of interest}

Author declares there are no conflicts of interest.

\section{Funding}

None. 